\title{
TINGKAT PEMAHAMAN MAHASISWA TENTANG PERLINDUNGAN HAK CIPTA ATAS KARYA TULIS (Studi Terhadap Mahasiswa UIN Maulana Malik Ibrahim Malang)
}

\author{
Khoirul Hidayah \\ Fakultas Syariah UIN Maulana Malik Ibrahim Malang \\ Email: khoirul.hidayah@yahoo.co.id
}

\begin{abstract}
Abstrak
The research background is the fenomena of infringement (copyright) in the Univercity. This research will analizes about The knowledge of UIN Maulana Malik Ibrahim student about the protection of copyright. The purpose of this research is to describe the influence of student knowledge about copyright with infringement (copyright). The research method is empirical research (sociological yurisprudence) with kwalitatif analyzes. The result of the research is the law attitude of students don't show the positive of law attitude in protection the copyrights. Although the students respect with the creation of mine (literary), but they have not the law attitude to obey the law of copyright.

Fenomena adanya pelanggaran hak cipta di lingkungan kampus telah melatarbelakangi penulis untuk mengadakan penelitian tentang tingkat pemahaman mahasiswa UIN Maulana Malik Ibrahim Malang mengenai perlindungan hak cipta. Penelitian bertujuan untuk mengetahui pengaruh pemahaman hukum mahasiswa tentang hak cipta dengan tingkat pelanggaran hukum hak cipta atas karya tulis. Jenis penelitian yang digunakan adalah penelitian empiris dengan pendekatan deskriptif kualitatif. Hasil penelitian menunjukkan bahwa tingkat pemahaman mahasiswa masih kurang. Sikap hukum mahasiswa belum menunjukkan sikap positif terhadap perlindungan hak cipta atas karya tulis. Meskipun mahasiswa mempunyai kehendak menghargai hasil karya orang lain, namun belum nampak sikap menerima undang-undang dalam perilaku sehari hari.
\end{abstract}

Kata kunci: Pemahaman, Hak cipta, Pelanggaran

Hak cipta merupakan bagian dari Hak atas Kekayaan Intelektual (HKI). Hak Cipta pada dasarnya telah dikenal sejak dahulu kala, akan tetapi konsep hukum hak cipta baru dikenal di Indonesia pada awal tahun 80-an. Setelah masa revolusi sampai tahun 1982, Indonesia masih menggunakan Undang-Undang pemerintah kolonial Belanda Auteurswet 1912 sampai Undang-Undang Hak Cipta pertama dibuat yaitu pada tahun 1982. Sejak menjadi bangsa yang merdeka, Indonesia mempunyai empat buah Undang-Undang yaitu UU No. 6 Tahun
1982, UU No. 7 Tahun 1987, UU No.12 Tahun 1997 dan UU No. 19 Tahun 2002. Perjanjian TRIPs (Trade Related Aspects of Intellectual Property Organization) telah mewajibkan bagi semua anggota WTO (World Trade Organization) yang meratifikasinya tunduk pada semua isi perjanjian, termasuk Indonesia yang sudah meratifikasi keanggotaannya melalui UndangUndang No.7 Tahun 1994 tentang The Agreement Establishing The World Trade Organization.

Perlindungan atas suatu karya cipta bertujuan 
untuk memenuhi prinsip keadilan. Hasil karya tersebut merupakan hasil (perwujudan) daya fikir/ ego tertinggi (alter ego) dari manusia, tentunya sebuah kewajiban bagi seseorang untuk menghargainya. Sebuah hasil karya yang sudah diciptakan membutuhkan pengorbanan, baik waktu, pikiran, dan biaya sehingga akan sangat tidak adil jika ada orang yang ingin merubah atau menirunya dan mendapatkan nilai ekonomis dari hasil karya tersebut.

Konsep hak cipta pertama kali berasal dari Eropa yang mempunyai budaya individualistis dan kapitalis. Indonesia telah meratifikasi TRIPs melalui keanggotaan WTO, sehingga secara yuridis Indonesia juga terikat dengan perlindungan hak cipta sebagaimana yang diatur dalam TRIPs. Penegakan hukum sebagaimana yang diatur di dalam TRIPs dan dalam undang-undang hak cipta tidak serta merta mudah diterapkan di Indonesia. Masyarakat Indonesia yang berbudaya komunal tentunya tidak mudah merubah kebiasaan dan budaya kebersamaan menjadi budaya individualistis sebagaimana yang diatur di dalam undangundang. Sehingga meskipun Undang-Undang No. 19 Tahun 2002 sudah berlaku selama 10 tahun dan ditambah dikeluarkannya fatwa haram oleh MUI pada tahun 2005, namun masih ditemukan banyak pelanggaran hak cipta di sekitar kita seperti beredarnya buku bajakan dan plagiasi karya tulis.

Keberadaan kota Malang sebagai kota pendidikan telah melahirkan banyak hasil karya tulis baik dalam bentuk penelitian maupun buku. Namun dengan banyaknya produk (hasil) karya tulis tersebut, ternyata juga dibarengi dengan tingginya pelanggaran hak cipta. Hal ini bisa dibuktikan dengan banyaknya buku bajakan yang beredar dan banyak ditemui di tempat fotocopi sekitar kampus. Pengalaman penulis sebagai dosen dan editor jurnal, ternyata juga sering menemukan hasil karya tulis mahasiswa dalam bentuk makalah ataupun skripsi yang tidak menulis buku rujukan dalam kutiban pada saat penulisan. Menurut Soerjono Soekamto, indikator kesadaran hukum masyarakat adalah meliputi pengetahuan hukum, pemahaman hukum, sikap hukum dan perilaku hukum. ${ }^{1}$ Dengan demikian, pelanggaran hak cipta karena faktor kesadaran hukum, bisa disebabkan adanya kurang pemahaman hukum oleh masyarakat.

Tugas tri dharma perguruan tinggi salah satunya adalah kewajiban membuat karya tulis. Seiring dengan tugasnya dalam proses pembelajaran, mahasiswa tidak pernah lepas dari tugas membuat makalah ataupun tugas akhir. Fenomena di lapangan sering ditemukan perilaku yang tidak baik, yaitu guna memenuhi tugas dosen dengan waktu terbatas dan faktor nilai, mahasiswa sering melakukan plagiasi terhadap karya tulis orang lain melalui media buku ataupun melalui media internet. Karena itu mahasiswa sebagai kelompok intelektual harus mampu menjadi teladan bagi generasi muda, misalnya berperilaku jujur dan bertanggungjawab. Seperti halnya dalam pembuatan karya tulis, mahasiswa harus memiliki sikap jujur dalam membuat suatu karya tulis. Membentuk perilaku jujur mahasiswa tidak terlepas dari peran lembaga untuk membentuk kultur berperilaku jujur dengan tidak melakukan plagiasi terhadap hasil karya orang lain. Hal inilah yang melatar belakangi penulis untuk membuat penelitian dengan judul: "Pemahaman Mahasiswa Terhadap Perlindungan Hak Cipta Atas Karya Tulis Menurut Undang-Undang dan Hukum Islam (Studi di UIN Maulana Malik Ibrahim Malang)".

\section{METODE PENELITIAN}

Jenis penelitian yang akan digunakan adalah jenis penelitian hukum empiris (sociological yurisprudence) yaitu penelitian yang menggunakan fenomena sosial dalam hal ini adalah fenomena mahasiswa dalam memahami perlindungan hak cipta di lingkungan UIN Maulana Malik Ibrahim. Pendekatan penelitian adalah pendekatan kualitatif, yaitu dengan menganalisis fenomena pemahaman mahasiswa tentang perlindungan hak cipta menurut undang-undang dan menurut hukum Islam dengan menggunakan teori kesadaran hukum. Sampel penelitian

\footnotetext{
${ }^{1}$ Munir Fuady, Sosiologi Hukum Kontemporer (Bandung, Citra Aditya Bakti, 2007), h. 77.
} 
adalah 60 mahasiswa yang tersebar di 6 fakultas dan pasca sarjana. Pengumpulkan data primer dilakukan dengan penyebaran kuesioner terhadap seluruh responden (60 mahasiswa), dan diambil secara acak sejumlah mahasiswa untuk dilakukan wawancara (perwakilan fakultas). Data sekunder akan diperoleh melalui studi kepustakaan yaitu dokumentasi buku, peraturan perundangundangan dan artikel terkait. Data yang diperoleh melalui wawancara dan kuesioner akan dianalisis dengan menggunakan metode deskriptif kualitatif dan kuantitatif yakni dengan melakukan klasifikasi, identifikasi dan menjelaskan hubungan antara data di lapangan dengan teori kesadaran hukum.

\section{HASIL DAN PEMBAHASAN}

\section{Hak Cipta Menurut Undang-Undang}

Hak cipta di Indonesia diatur di dalam UU No. 19 Tahun 2002. Hak cipta merupakan hak eksklusif bagi pencipta atau pemegang hak cipta untuk mengumumkan atau memperbanyak ciptaannya, yang timbul secara otomatis setelah suatu ciptaan dilahirkan tanpa mengurangi pembatasan menurut peraturan perundangundangan yang berlaku. TRIPs mengakui bahwa ciptaan yang layak mendapat perlindungan hukum manakala ciptaan tersebut merupakan ekspresi atau perwujudan ide (Pasal 9 ayat 2 TRIPs). Selain itu syarat keaslian atau originality, maksudnya adalah ciptaan mempunyai bentuk yang khas dan menunjukkan keaslian atas dasar kemampuan dan kreatifitasnya yang bersifat pribadi dari si pencipta karena ciptaan adalah ego tertinggi (alter ego) dari si pencipta ${ }^{2}$.

Ekspresi atau perwujudan ide dalam sebuah karya cipta yang dimaksud adalah bahwa sebuah hasil karya tidak bisa diberikan hak eksklusif apabila hanya berupa ide saja, namun harus dalam bentuk nyata atau berwujud (dalam literatur asing sering disebut fixation). Berikut ini akan diberikan contoh perbedaan ide dan perwujudan ide (fixation):

Apabila seseorang mempunyai ide menulis

${ }^{2}$ Eddy Damian, Hukum Hak Cipta (Bandung: Alumni, 2003), h. 132. cerita pengalaman pribadi dalam bentuk novel, maka cerita pengalaman tidak akan mendapatkan perlindungan, apabila tidak diwujudkan dalam bentuk tertulis (seperti novel atau karya lain yang bisa dilihat, dibaca atau didengar). Kemudian apabila seorang penyanyi mempunyai ide menceritakan suasana Yogjakarta dalam bentuk lagu, suasana Yogyakarta adalah sesuatu yang biasa, namun apabila penyanyi menuangkan dalam bentuk lagu dan bisa didengar, maka akan menjadi sebuah karya yang bisa dilindungi hak cipta.

Selain ekspresi, sebuah karya juga harus dalam bentuk khas dan bersifat orisinil, bukan meniru karya orang lain atau karya publik domain, sebagaimana di atur di dalam Pasal 1 Angka 2 dan 3 Undang-Undang No. 19 Tahun 2002 (UUHC). Untuk mempermudah memahami syarat perlindungan terhadap hak cipta, maka berdasarkan UU hak cipta adalah sebagai berikut: (a) Berwujud atau bentuk nyata (fixation); (b) Bersifat pribadi atau khas; (c) Bersifat asli (original). Sedangkan hak cipta dalam pengertian pemberian hak eksklusif yang di atur di dalam UUHC terdapat 2 macam, yaitu: (a) Hak cipta (pasal 1 angka 1): meliputi pencipta dan penerima hak; (b) Hak terkait atau neightbouring rights (pasal 1 angka 9): meliputi pelaku, produser rekaman suara dan lembaga penyiaran.

\section{Pencipta Menurut Undang-Undang}

Untuk menjelaskan siapa saja yang dianggap sebagai pencipta di dalam undang-undang hak cipta, maka berikut ini pasal yang mengatur tentang pencipta. Pertama, Pasal 1 Angka 2 UUHC: "Pencipta adalah seorang atau beberapa orang secara bersama-sama yang atas inspirasinya melahirkan suatu Ciptaan berdasarkan kemampuan pikiran, imajinasi, kecekatan, keterampilan, atau keahlian yang dituangkan ke dalam bentuk yang khas dan bersifat pribadi." Kedua, Pasal 9 UUHC: "Jika suatu badan hukum mengumumkan bahwa ciptaan berasal dari padanya dengan tidak menyebut seseorang sebagai penciptanya, badan hukum tersebut dianggap sebagai penciptanya, kecuali jika terbukti sebaliknya." 
Pasal di atas menjelaskan, bahwa ada dua macam pencipta atau subyek hukum yang bisa diberikan perlindungan hak cipta, yaitu perseorangan dan badan hukum. Apabila sebuah ciptaan diciptakan oleh beberapa orang (joint works), menurut Pasal 6 UUHC yang diakui sebagai pencipta adalah ketua tim atau orang yang memimpin atau yang mengawasi pekerjaan atau orang yang menghimpun ciptaan tersebut. Sedangkan menurut WIPO hasil ciptaan melalui joint works diakui oleh semua pihak yang menyumbangkan karyanya (joint owners of the entire work) $)^{3}$. Disamping itu, sebuah karya cipta bisa dimungkinkan dimiliki oleh badan usaha. Hasil karya yang dihasilkan dari perorangan, namun apabila terikat perjanjian dengan sebuah perusahaan, tentunya hasil karya cipta akan menjadi hak milik perusahaan.

Untuk sebuah karya cipta tidak diketahui penciptanya, maka pemegang hak cipta adalah negara. Berikut ini hasil karya yang dimiliki oleh negara (Pasal 10UUHC): (1) Karya peninggalan prasejarah, sejarah dan benda budaya nasional; (2) Folklore, sekumpulan ciptaan tradisional, baik yang dibuat oleh kelompok maupun perorangan dalam masyarakat, yang menunjukkan identitas sosial dan budayanya berdasarkan standar dan nilai-nilai yang diucapkan atau diikuti secara turun temurun, termasuk: (a) cerita rakyat, puisi rakyat; (b) lagu-lagu rakyat dan musik instrumen tradisional; (c) tari-tarian rakyat, permainan tradisional; dan (d) perhiasan, kerajinan tangan, pakaian, instrumen musik dan tenun tradisional (penjelasan Pasal 10 UUHC).

Menurut Pasal 12 UUHC, dalam undangundang ini ciptaan yang dilindungi adalah ciptaan dalam bidang ilmu pengetahuan, seni, dan sastra, yang mencakup: (a) buku, program komputer, pamflet, perwajahan (lay out) karya tulis yang diterbitkan, dan semua hasil karya tulis lain; (b) ceramah, kuliah, pidato, dan Ciptaan lain yang sejenis dengan itu; (c) alat peraga yang dibuat untuk kepentingan pendidikan dan ilmu pengetahuan; (d) lagu atau musik dengan atau tanpa teks; (e) drama

${ }^{3}$ Tomi Suryo Utomo, Hak Kekayaan Intelektual di Era Globalisasi (Yogjakarta: Graha Ilmu, 2009),h. 78. atau drama musikal, tari, koreografi, pewayangan, dan pantomim; (f) seni rupa dalam segala bentuk seperti seni lukis, gambar, seni ukir, seni kaligrafi, seni pahat, seni patung, kolase, dan seni terapan; (g) arsitektur; (g) peta;seni batik; (h) fotografi; (i) sinematografi; (j) terjemahan, tafsir, saduran, bunga rampai, database, dan karya lain dari hasil pengalihwujudan.

Sedangkan jangka waktu yang diperlukan dalam upaya perlindungan hak cipta atas ciptaan menurut Pasal 29 dan 30 UUHC yaitu: (a) buku, pamflet, dan semua hasil karya tulis lain; (b) drama atau drama musikal, tari, koreografi; (c) segala bentuk seni rupa, seperti seni lukis, seni pahat, dan seni patung; (d) seni batik; (e) lagu atau musik dengan atau tanpa teks; (f) arsitektur; (g) ceramah, kuliah, pidato dan Ciptaan sejenis lain; (h) alat peraga; (i) peta; (j) terjemahan, tafsir, saduran, dan bunga rampai berlaku selama hidup pencipta dan terus berlangsung hingga 50 (lima puluh) tahun setelah pencipta meninggal dunia.

Hak pemilik atas karya cipta tidak serta merta menjadikan seseorang untuk monopoli dan memperkaya diri sendiri atas hak ekonomi yang sudah diperolehnya. Untuk menyeimbangkan hak pemilik dengan kepentingan masyarakat, maka UUHC mengijinkan penggunaan ciptaanciptaan tertentu tanpa perlu ijin pencipta, pengaturan ini terdapat di dalam Pasal 15 UUHC: (a) Penggunaan ciptaan pihak lain untuk kepentingan pendidikan, penelitian, penulisan karya ilmiah, penyusunan laporan, penulisan kritik atau tinjauan suatu masalah dengan tidak merugikan kepentingan yang wajar dari Pencipta; (b) pengambilan ciptaan pihak lain, baik seluruhnya maupun sebagian, guna keperluan pembelaan di dalam atau di luar pengadilan; (c) Pengambilan ciptaan pihak lain, baik seluruhnya maupun sebagian, guna keperluan: (i) ceramah yang semata-mata untuk tujuan pendidikan dan ilmu pengetahuan; atau (ii) pertunjukan atau pementasan yang tidak dipungut bayaran dengan ketentuan tidak merugikan kepentingan yang wajar dari pencipta; (d) Perbanyakan suatu ciptaan bidang ilmu pengetahuan, seni, dan sastra dalam huruf braille guna keperluan para tunanetra, kecuali jika perbanyakan itu bersifat komersial; (e) Perbanyakan suatu ciptaan selain program komputer, secara 
terbatas dengan cara atau alat apa pun atau proses yang serupa oleh perpustakaan umum, lembaga ilmu pengetahuan atau pendidikan, dan pusat dokumentasi yang non komersial semata-mata untuk keperluan aktivitasnya; (f) Perubahan yang dilakukan berdasarkan pertimbangan pelaksanaan teknis atas karya arsitektur, seperti ciptaan bangunan; ( $g$ ) Pembuatan salinan cadangan suatu program komputer oleh pemilik Program Komputer yang dilakukan semata-mata untuk digunakan sendiri.

Hak yang dimiliki pencipta dan pemegang hak cipta terbagi menjadi dua yaitu hak moral dan hak ekonomi. Berikut ini akan dijelaskan apa yang dimaksud hak yang dimiliki pencipta menurut UUHC. Hak Moral adalah hak yang melekat pada diri pencipta yaitu hak untuk selalu dicantumkan nama pencipta dalam setiap ciptaannya dan hak atas keutuhan ciptaannya, tidak dapat dihilangkan atau dihapus tanpa alasan apapun, walaupun hak cipta ataupun hak terkait telah dialihkan. Hak moral diatur di dalam Pasal 24 UUHC. Secara umum, hak moral berhubungan dengan hubungan spirit atau jiwa dari pencipta dengan karyanya. Secara historis, hak moral berasal dari tradisi droit d'auteur (Perancis) yang melihat kreasi intelektual sebagai sebuah perwujudan semangat atau jiwa dari pencipta. Sedangkan negara Anglo-Saxon menganggap hak cipta dan hak terkait sebagai hak kebendaan yang murni dan sederhana yang dapat dibeli, dijual, disewakan layaknya membeli sebuah rumah atau mobil. Perbedaan persepsi inilah yang membedakan perlindungan hukum terhadap hak moral di negara Eropa Kontinental dan Anglo-Saxon. Negara Eropa pada umumnya memberikan perlindungan yang kuat sedangkan negara Anglo-Saxon tidak seketat negara Eropa Kontinental. Ada 2 jenis hak moral, yaitu: ${ }^{4}$ (a) Hak untuk diakui sebagai pencipta (authorsip right atau paternity right). Jika karya dari seorang pencipta diperbanyak, diumumkan atau dipamerkan di hadapan publik, nama pencipta harus tercantum pada karya tersebut; (b) Hak keutuhan karya (the right to protect the integrity of the work). Hak ini akan mencegah

${ }^{4}$ Ibid, h. 89 tindakan perubahan terhadap ciptaan yang berpotensi merusak reputasi dan kehormatan pencipta. Menurut penjelasan Pasal 24 Ayat (2) UUHC, perubahan tersebut dapat berupa pemutarbalikan, pemotongan, perusakan, dan penggantian yang berhubungan dengan karya cipta.

Hak ekonomi adalah hak yang dimiliki oleh pencipta atau pemegang hak cipta untuk mendapatkan manfaat ekonomi dari ciptaannya, atau hak mengijinkan atau melarang orang lain untuk mengumumkan dan atau memperbanyak ciptaannya. Hak ekonomi meliputi: ${ }^{5}$ (a) Hak penggandaan (reproduction right); (b) Hak penyebarluasan (distribution right); (c) Hak adaptasi (adaptation right), meliputi hak penerjemahan, hak dramatisasi, hak film; (d) Hak atas rekaman suara (mechanical right); (e) Hak atas program siaran (broadcasting right).

\section{Upaya Penyelesaian Hukum}

Undang-undang hak cipta memberikan pilihan penyelesaian hukum bagi pencipta atau pemegang hak cipta yang haknya dilanggar oleh pihak lain. Mekanisme penyelesaian bagi pencipta yang ingin mempertahankan haknya: Pertama, gugatan perdata yang mekanismenya diatur di dalam Pasal 56 UUHC. Pemegang hak cipta berhak mengajukan gugatan ganti rugi kepada pengadilan niaga atas pelanggaran hak ciptaannya dan meminta penyitaan terhadap benda yang diumumkan atau hasil perbanyakan ciptaan itu. Pemegang hak cipta juga berhak memohon kepada pengadilan niaga agar memerintahkan penyerahan seluruh atau sebagian penghasilan yang diperoleh dari penyelenggaraan ceramah, pertemuan ilmiah, pertunjukan atau pameran karya, yang merupakan hasil pelanggaran hak cipta. Sebelum menjatuhkan putusan akhir dan untuk mencegah kerugian yang lebih besar pada pihak yang haknya dilanggar, HKI dapat memerintahkan pelanggar untuk menghentikan kegiatan pengumuman dan/atau perbanyakan ciptaan atau barang yang merupakan hasil

${ }^{5} \mathrm{M}$, Djubaedillah Djumhana, R, Hak Kekayaan Intelektual di Indonesia. (Bandung: Citra Aditya Bakti, 1993),h. 51-54 
pelanggaran hak cipta. Pelanggaran atas hak moral tetap dapat diajukan oleh pencipta atau ahli warisnya bila pencipta telah meninggal dunia (Pasal 55 UUHC). Kedua, tuntutan pidana pelanggaran hak cipta yang diatur di dalam Pasal 72 UUHC. Pengajuan gugatan perdata tetap bisa dilakukan bersama tuntutan pidana. Proses perdata tidak menggugurkan hak negara untuk melakukan tuntutan pidana. Ketiga, penyelesaian sengketa melalui alternatif penyelesaian sengketa/ADR (Alternative Dispute Resolution) dalam bentuk negosiasi, mediasi, konsiliasi, dan cara lain yang dipilih oleh para pihak sesuai dengan Undang-undang yang berlaku (Pasal 65 UUHC).

\section{Pemahaman Mahasiswa Tentang Hak Cipta}

Pada penelitian ini akan mengkaji sejauh mana pemahaman mahasiswa UIN Maliki Malang tentang perlindungan hukum hak cipta. Pemahaman hukum menurut Soerjono Soekamto adalah seseorang warga masyarakat yang mempunyai pengetahuan dan pemahaman mengenai aturan-aturan tertentu, terutama dari segi isinya. Pemahaman hukum jika merujuk pada teori Soerjono tentang kesadaran hukum, maka pemahaman hukum merupakan salah satu faktor terwujudnya kesadaran hukum dalam sebuah masyarakat. Pada penelitian ini, setelah mengetahui pemahaman hukum mahasiswa, diharapkan dapat dibuat sebuah upaya atau langkah selanjutnya untuk mewujudkan kesadaran hukum bagi mahasiswa di lingkungan UIN Maliki Malang.
Pemahaman hukum mahasiswa tentang hak cipta jika merujuk pada pengertian Soerjono, maka pemahaman mahasiswa dapat diukur melalui beberapa indikator. Pada penelitian ini, untuk mengukur pemahaman hukum mahasiswa UIN Maliki tentang hak cipta, maka penulis menggunakan beberapa indikator. Berikut ini indikator yang dipakai untuk mengetahui sejauhmana pemahaman hukum mahasiswa tentang hak cipta atas karya tulis: (1) Pengetahuan Undang-Undang No. 19 Tahun 2002 tentang Hak Cipta; (2) Pengetahuan tentang perlindungan hak cipta atas karya tulis; (3) Pengetahuan tentang hak ekonomis dan hak moral dalam perlindungan hak cipta; (4) Pengetahuan tentang pasal gugatan ganti rugi dan pasal pidana terhadap pelanggaran hak cipta atas karya tulis. Berikut ini adalah hasil kuesioner yang dilakukan terhadap 60 mahasiswa UIN Malang.

Tabel 1

Daftar Responden

\begin{tabular}{clc}
\hline No & \multicolumn{1}{c}{ Fakultas } & Jumlah \\
\hline 1 & Syariah & 9 \\
\hline 2 & Tarbiyah & 9 \\
\hline 3 & Psikologi & 9 \\
\hline 4 & Ekonomi & 9 \\
\hline 5 & Saintek & 9 \\
\hline 6 & Humbud & 9 \\
\hline 7 & Pascasarjana & 6 \\
\hline & Jumlah $(\mathrm{n})$ & 60 \\
\hline
\end{tabular}

Tabel 2

Tabulasi Data Pemahaman Mahasiswa

\begin{tabular}{|c|c|c|c|}
\hline No & Materi kuesioner & \multicolumn{2}{|c|}{ Hasil kuesioner, $\mathrm{n}=60$} \\
\hline \multirow[t]{2}{*}{1} & \multirow{2}{*}{$\begin{array}{l}\text { Pengetahuan keberadaan Undang-Undang No. } \\
19 \text { Tahun } 2002 \text { tentang Hak Cipta }\end{array}$} & mengetahui & $\begin{array}{c}\text { tidak } \\
\text { mengetahui }\end{array}$ \\
\hline & & $41.66 \%$ & $58.34 \%$ \\
\hline \multirow[t]{2}{*}{2} & \multirow[t]{2}{*}{ Pengetahuan tentang hak cipta atas karya tulis } & mengetahui & $\begin{array}{c}\text { tidak } \\
\text { mengetahui }\end{array}$ \\
\hline & & $53.33 \%$ & $46.67 \%$ \\
\hline
\end{tabular}




\begin{tabular}{|c|c|c|c|}
\hline \multirow[t]{2}{*}{3} & \multirow{2}{*}{$\begin{array}{l}\text { Pengetahuan tentang hak ekonomis dan hak } \\
\text { moral atas karya tulis }\end{array}$} & mengetahui & $\begin{array}{c}\text { tidak } \\
\text { mengetahui }\end{array}$ \\
\hline & & $55 \%$ & $45 \%$ \\
\hline \multirow[t]{2}{*}{4} & \multirow{2}{*}{$\begin{array}{l}\text { Pengetahuan pasal gugatan ganti rugi dan pasal } \\
\text { pidana terhadap pelanggaran karya tulis }\end{array}$} & mengetahui & $\begin{array}{c}\text { tidak } \\
\text { mengetahui }\end{array}$ \\
\hline & & $73.33 \%$ & $26.67 \%$ \\
\hline
\end{tabular}

Jumlah prosentase mahasiswa yang mempunyai pemahaman hukum adalah: $(41.66 \%$ $+53.33 \%+55 \%+73.33 \%): 4=55,83 \%$. Jadi jumlah mahasiswa yang paham adalah: $55.83 \%$ × $60=$ 33 mahasiswa. Indikator pertama pemahaman hukum mahasiswa adalah pengetahuan keberadaan Undang-Undang No. 19 Tahun 2002 tentang Hak Cipta, data di lapangan menunjukkan bahwa sebagian mahasiswa mengetahui keberadaan undang-undang hak cipta yaitu sebanyak 25 mahasiswa atau $41,66 \%$, sisanya sejumlah $58,34 \%$ mahasiswa belum mengetahui. Angka ini menunjukkan bahwa masih banyak mahasiswa yang belum mengetahui keberadaan undang-undang tersebut. Berdasarkan hasil wawancara juga menunjukkan bahwa dari sejumlah mahasiswa yang mengetahui keberadaan undang-undang hak cipta, tapi tidak mengetahui isi undangundang secara jelas, karena mereka tidak pernah membaca undang-undang. Mahasiswa juga menjelaskan bahwa tidak pernah mengenal undang-undang hak cipta melalui perkuliahan, sebab mereka hanya sering mendengarkan istilahnya saja yaitu melalui buku, media cetak dan elektronik.

Indikator yang kedua adalah pengetahuan tentang hak cipta atas karya tulis. Perlindungan hak cipta atas karya tulis tertuang di dalam Pasal 12 (1) UUHC. Berdasarkan hasil wawancara diketahui bahwa ada 32 mahasiswa atau 53,33\% dari mahasiswa mengetahui tentang perlindungan atas karya cipta. Sebanyak $46,67 \%$ mahasiswa tidak mengetahui bahwa sebuah karya tulis dapat dilindungi oleh hukum. Mahasiswa yang tidak mengetahui mempunyai pemahaman bahwa hanya karya cipta dalam bentuk buku saja yang dilindungi. Meskipun mahasiswa tidak pernah membaca undang-undang, namun mahasiswa mengetahui perlindungan atas karya tulis melalui media massa atau media elektronik.

Indikator yang ketiga adalah pengetahuan tentang hak ekonomis dan hak moral. Hak ekonomis atas suatu karya cipta diatur di dalam Pasal 2 (1) UUHC: Hak Cipta merupakan hak eksklusif bagi Pencipta atau Pemegang Hak Cipta untuk mengumumkan atau memperbanyak Ciptaannya, yang timbul secara otomatis setelah suatu ciptaan dilahirkan tanpa mengurangi pembatasan menurut peraturan perundangundangan yang berlaku. Pasal diatas menjelaskan bahwa pencipta mempunyai hak eksklusif untuk mengumumkan atau memperbanyak ciptaannya atau memberikan izin kepada pihak lain. Pengaturan hak moral selanjutnya diatur dalam Pasal 24. Pasal tersebut menjelaskan bahwa pencipta berhak namanya dicantumkan dalam ciptaannya dan ciptaannya tidak boleh diubah kecuali dengan persetujuan pencipta. Berdasarkan hasil kuesioner di lapangan, mahasiswa yang mengetahui tentang kedua hak tersebut sejumlah 33 mahasiswa atau 55\% dan $45 \%$ mahasiswa tidak mengetahuinya. Hasil wawancara menunjukkan bahwa mahasiswa lebih mengetahui hak ekonomis dibandingkan hak moral. Mahasiswa hanya mengetahui bahwa pelanggaran atas karya cipta dapat merugikan secara ekonomis pencipta (penulis), sedangkan hak moral yang dimaksud di dalam undang-undang tidak banyak dipahami oleh mahasiswa.

Indikator yang keempat adalah pengetahuan tentang pasal gugatan ganti-rugi dan pasal pidana terhadap pelanggaran hak cipta atas karya tulis. UUHC mengatur hal tersebut di dalam Pasal 58 dan Pasal 72. Berdasarkan hasil kuesioner di lapangan menunjukkan bahwa mahasiswa yang mengetahui ketentuan ini sebanyak 44 mahasiswa atau $73 \%$, meskipun 
tidak bisa menyebutkan pasal, namun mahasiswa mengetahui ketentuan tersebut yaitu melalui buku, media masa dan elektronik. Penjelasan hasil data dengan mengunakan empat indikator di atas dapat menunjukkan bahwa mahasiswa UIN Maliki Malang yang paham terhadap perlindungan hukum atas sebuah karya cipta masih separo dari jumlah mahasiswa yang ada atau sebanyak $55.83 \%$. Keadaan ini perlu dijadikan perhatian bagi lembaga untuk memberikan pemahaman terhadap sebagian mahasiwa yang masih belum mengerti. Pemahaman hukum mahasiswa atas karya cipta mempunyai dampak terhadap perilaku mahasiswa untuk memegang prinsip kejujuran dalam membuat sebuah karya tulis dan tidak melakukan pelanggaran dalam bentuk plagiasi, seperti membuat artikel (makalah tugas dosen), membuat skripsi dan tesis.

UIN Maliki sebagailembaga pendidikan tinggi mempunyai kewajiban untuk menumbuhkan budaya akademik yang jujur dan menjunjung tinggi nilai-nilai moral akademik dalam melaksanakan tugas Tri Dharma Perguruan Tinggi. Melalui nilai Ulul Albab yang menjadi ciri khas UIN Maliki Malang tentunya harus mampu menciptakan manusia-manusia yang produktif dan jujur dalam kehidupan seharihari. Proses pembelajaran yang jujur melalui pemahaman hukum hak atas karya tulis harus dilakukan secara integratif oleh sebuah sistem pembelajaran pada setiap matakuliah.

Nilai-nilai ajaran agama diyakini mempunyai kebenaran mutlak bagi penganutnya. Masyarakat yang beragama memandang agama sebagai hukum Allah yang wajib ditaati. Ritual-ritual keagamaan harus dilaksanakan dengan rutin, salah satunya adalah keharusan melakukan perintah atau larangan dalam agama adalah kenyataan hukum sosial yang berlaku. Sanksi bagi pelanggar ajaran agama telah disebutkan secara tekstual yaitu melalui ayat-ayat al Qur'an dan sunnah Rasul. Pelaksanaan sanksi yang merujuk pada ajaran agama bisa bersifat langsung atau tidak langsung karena agama melalui kitab sucinya menyatakan adanya sanksi di dunia dan sanksi akhirat. ${ }^{6}$

Norma sosial dalam masyarakat banyak yang bersumber dari agama. Perilaku tradisional yang kuat dan membentuk karakteristik sosial yang kolektif dan homogen bisa dibentuk melalui agama. Agama bukan sekedar ajaran Ilahi dan para Nabi, namun agama juga merupakan gejala hukum yang kemudian menjadi hukum sosial dalam masyarakat. Kepercayaan terhadap sakralitas ajaran agama memudahkan masyarakat untuk mentradisikannya sehingga terbentuknya sosial normatif yang lebih efektif. Sumber perilaku sosial lebih besar didominasi oleh loyalitas terhadap sumber ajaran yang berlaku dan diyakini oleh pemeluknya. Hukum yang ditaati merupakan perwujudan kesadaran religiusitas sosial. ${ }^{7}$

Ijtihad dalam bentuk fatwa yang dibuat oleh MUIadalah salah satu upaya yang dilakukan oleh para ulama dalam menyelesaikan permasalahan terkini, fatwa merupakan salah satu sumber norma agama yang dapat ditaati oleh masyarakat muslim di Indonesia. Meskipun fatwa bukan sebagai hukum formil, namun fatwa bisa dijadikan sebagai pedoman bagi umat muslim dalam menyelesaikan permasalahan fiqh dalam kehidupan sehari-hari. karenanya pada penelitian ini penulis ingin mengetahui pengetahuan mahasiswa terkait ijtihad perlindungan hak cipta melalui fatwa MUI. Pengetahuan hukum Islam sebagai sumber moral dalam perilaku masyarakat dalam hal ini mahasiswa, tentunya mampu mempengaruhi perilaku mahasiswa dalam mewujudkan kesadaran hukum. Fatwa sebagai bentuk aturan agama tentunya dapat membentuk karakter sosial yang taat pada hukum. Pemahaman mahasiswa tentang hak cipta menurut hukum Islam dapat diketahui melalui pengetahuan mahasiswa tentang fatwa MUI yang mengatur perlindungan hak cipta. Berikut ini hasil wawancara dan kuesioner terhadap responden mahasiswa.

\footnotetext{
${ }^{6}$ Beni Ahmad Saebani, Sosiologi Hukum (Bandung: Pustaka Setia Bandung, 2006), h. 54.
} 
Tabel 3

Data Pengetahuan Mahasiswa tentang Fatwa MUI

\begin{tabular}{|c|c|c|c|c|c|}
\hline No & Materi uesioner & \multicolumn{4}{|c|}{ Hasil Wawancara, n=60 } \\
\hline \multirow{2}{*}{1} & \multirow{2}{*}{$\begin{array}{l}\text { Pengetahuan fatwa MUI tentang Perlindungan } \\
\text { Hak Kekayaan Intelektual (HKI) }\end{array}$} & \multicolumn{2}{|c|}{ mengetahui } & \multicolumn{2}{|c|}{ tidak mengetahui } \\
\hline & & 17 & $28,33 \%$ & 43 & $71.67 \%$ \\
\hline
\end{tabular}

Pada tabel di atas menunjukkan bahwa jumlah mahasiswa yang mengetahui konsep hak cipta melalui fatwa MUI hanya berjumlah 17 mahasiswa atau sebanyak $28,33 \%$, sedangkan yang tidak mengetahui jumlahnya lebih besar yaitu $71.67 \%$. Pemahaman mahasiswa tentang perlindungan hak cipta menurut hukum Islam dalam penelitianini diukur dengan menggunakan indikator pengetahuan mahasiswa tentang fatwa MUI. Jika mahasiswa tidak mengetahui keberadaan fatwa MUI tentang Perlindungan Hak Kekayaan Intelektual, maka mahasiswa dianggap belum memahami perlindungan hak cipta atas karya tulis menurut hukum Islam. Meskipun berdasarkan hasil wawancara di lapangan, responden pernah mendapatkan pengetahuan dari kyai/ulama (guru mengaji responden) bahwa perlindungan hak cipta tidak sesuai dengan ajaran Islam, namun pendapat tersebut tidak dijadikan indikator oleh peneliti. Pendapat pribadi ulama adalah bukan hasil kesepakatan dan tidak bisa berlaku umum. Fatwa MUI adalah hasil kesepakatan ulama atas sebuah permasalahan umat muslim di Indonesia yaitu dengan melalui proses ijtihad. Dengan demikian fatwa MUI adalah bentuk pendapat ulama yang bisa digunakan sebagai petunjuk dalam pelaksanaan hukum Islam di Indonesia.

Pada penelitian ini sebenarnya difokuskan pada pemahaman hukum perlindungan hak cipta menurut undang-undang. Namun penulis berpendapat bahwa keberadaan hukum Islam juga bisa menjadi kajian, karena masyarakat Indonesia yang mayoritas beragama Islam selain menggunakan hukum positif juga menggunakan hukum Islam dalam praktek kehidupan sehari-harinya. Penulis beranggapan bahwa pemahaman hukum Islam secara tidak langsung juga dapat membantu dalam proses terciptanya masyarakat yang mempunyai kesadaran hukum.

Keberadaan fatwa MUIyang sudah berjalan 7 tahun ternyata belum bisa memberikan pengaruh besar terhadap praktek pelanggaran hak cipta. Banyak masyarakat yang tidak tahu tentang fatwa tersebut. Hal ini terbukti dari hasil kuesioner dan wawancara yang sudah dilakukan terhadap 60 mahasiswa, ternyata yang mengetahui fatwa MUI hanya sejumlah $28,33 \%$. Sistem hukum di Indonesia tidak menganggap fatwa sebagai tata hukum formil yang mengikat, sehingga tidak ada kewajiban bagi masyarakat untuk mengetahui dan taat pada fatwa MUI. Namun demikian hukum Islam sebagai hukum yang hidup di masyarakat keberadaan hukum Islam dalam bentuk fatwa MUI bisa digunakan sebagai sumber moral dalam kehidupan sehari-sehari.

Fatwa MUI hanya bersifat melengkapi dan membantu dalam membentuk budaya hukum masyarakat Indonesia yang mayoritas Islam untuk menjadi masyarakat yang sadar hukum atau taat pada hukum. A pabila terjadi pelanggaran hak cipta yang dilakukan oleh seseorang tentunya tetap kembali pada peraturan perundang-undangan yang berlaku. Fatwa MUI diupayakan untuk disosialisasikan baik melalui media publik ataupun lembaga pendidikan. Bentuk sosialisasi yang bisa digunakan adalah melalui proses pengajaran, seperti melalui mata kuliah hukum HKI dan metode penelitian. Fatwa MUI sebagai hukum Islam bisa dijadikan sumber nilai oleh masyarakat khususnya mahasiswa UIN Maliki untuk membentuk perilaku sosial dan perilaku hukum yang baik. Perilaku sosial yang baik tentunya dapat dilihat melalui terwujudnya perilaku mahasiswa UIN Maliki yang mau menghargai hasil karya tulis orang lain dan 
mempunyai sikap jujur dalam membuat sebuah karya tulis, sedangkan perilaku hukum yang baik dapat dilihat melalui terwujudnya mahasiswa yang taat hukum, tidak melakukan pelanggaran hak cipta atas karya tulis, tidak ada plagiasi dan pembajakan.

\section{Pengaruh Pemahaman Hukum Mahasiswa dengan Tingkat Pelanggaran Hukum Hak Cipta}

Bentuk pelanggaran hukum hak cipta yang sering kita temui merupakan bentuk permasalahan dalam proses penegakan hukum di Indonesia. Pelanggaran hak cipta atas karya tulis adalah salah satu bentuk pelanggaran yang sering kita temui di sekitar kita yaitu di lingkungan akademik baik dengan cara disengaja ataupun tidak disengaja. Fenomena ini tentunya dapat dijadikan sebuah kajian sosiologi hukum yaitu bagaimana pelaksanaan sebuah peraturan dalam hal ini undang-undang hak cipta dapat berlaku efektif sesuai dengan tujuan dibuatnya peraturan. Hal ini tentunya membutuhkan waktu yang cukup lama bagi masyarakat Indonesia yang berbudaya sosial untuk segera menyesuaikan dengan perlindungan hak cipta yang berlatar belakang budaya individualistis.

Berdasarkan data hasil kuesioner dan wawancara mahasiswa di lapangan menunjukkan bahwa sebanyak 33 mahasiswa UIN Maliki $(55,83 \%)$ sudah mempunyai pemahaman yang baik tentang perlindungan hak cipta atas karya tulis, sedangkan sisanya masih belum mempunyai pemahaman hukum. Pada saat dilakukan penghitungan dan analisa data kuesioner di lapangan telah ditemukan hasil yang menunjukkan pengaruh pemahaman hukum mahasiswa terhadap tingkat pelanggaran hukum hak cipta. Berikut ini adalah hasil kuesioner yang dapat menunjukkan pelanggaran hak cipta oleh mahasiswa.

Tabel 4

Hasil Tabulasi Data Pelanggaran Hak Cipta

\begin{tabular}{clrrrr}
\hline No & \multicolumn{1}{c}{ Materi kuesioner } & \multicolumn{3}{c}{ Hasil Kuesioner, n=60 } \\
\hline & $\begin{array}{l}\text { Menggunakan artikel orang lain dan } \\
\text { mengganti nama penulis asli dengan } \\
\text { nama sendiri }\end{array}$ & 19 & $31,66 \%$ & 41 & $68,34 \%$ \\
\cline { 2 - 6 } 2 & $\begin{array}{l}\text { Tidak mencantumkan kutiban dalam } \\
\text { penulisan karya tulis }\end{array}$ & 36 & $60 \%$ & 24 & $40 \%$ \\
\hline 3 & Melakukan fotocopy terhadap buku asli & 54 & $90 \%$ & 6 & $10 \%$ \\
\hline
\end{tabular}

Pelanggaran hak cipta atas karya tulis jika merujuk pada undang-undang hak cipta terdapat 2 macam bentuk pelanggaran, yaitu: (a) Pelanggaran hak moral; (b) Pelanggaran hak ekonomis. Praktek pelanggaran hak moral terhadap hasil karya tulis biasanya dilakukan dalam bentuk plagiasi. Praktek plagiasi atau plagiarisme diartikan sebagai sebuah perbuatan mengambil dan menyalin hasil karya orang lain tanpa izin pemiliknya. Plagiat karya tulis merupakan bentuk pengambilan karya tulis orang lain dan menjadikannya sebagai hasil karya tulis sendiri, misalnya mengakui dan menerbitkan karya tulis orang lain atas nama sendiri. Pasal 1 Ayat 1 Peraturan Mendiknas No. 17 Tahun 2010 menjelaskan bahwa plagiat adalah perbuatan secara sengaja atau tidak sengaja dalam memperoleh atau mencoba memperoleh kredit atau nilai untuk suatu karya ilmiah, dengan mengutip sebagian atau seluruh karya dan/ atau karya ilmiah orang lain, tanpa menyatakan sumber secara tepat dan memadai. Praktek pelanggaran berikutnya yang diatur di dalam undang- 
undang adalah pelanggaran hak ekonomis. Pelanggaran hak ekonomis atas karya tulis ini bisa dalam bentuk praktek pembajakan hasil karya tulis. Pembajakan buku bisa dalam bentuk mengumumkan dan memperbanyak hasil karya tulis tanpa seijin pencipta/penulis sebagaimana yang dimaksud di dalam Pasal 2 Undang-Undang Hak Cipta.

Media elektronik seperti penggunaan internet sangat membuka peluang terjadinya praktek plagiasi. Cara yang paling mudah dan sering dilakukan mahasiswa adalah melalui cara copy paste artikel atau bentuk karya tulis lain yang disediakan di internet. Beberapa bentuk praktek plagiasi karya tulis bisa dilakukan dengan beberapa cara. Berdasarkan hasil pengamatan, berikut ini beberapa cara yang sering dilakukan oleh mahasiswa: (a) Menggunakan artikel atau karya tulis milik orang lain dan menggantinya dengan nama sendiri; (b) Melakukan copy paste artikel/karya tulis orang lain dan tanpa menyebut sumbernya (tanpa menggunakan kutiban); (c) Menggunakan gagasan/ide orang lain melalui karya tulis dan tanpa menyebut pemilik gagasan/ide (hasil penelitian).

Pemahaman hukum mahasiswa ternyata tidak disertai dengan perilaku yang baik dalam menghargai karya orang lain. Hal ini dibuktikan dengan hasil kuesioner yang menunjukkan bahwa terdapat 19 mahasiswa atau $31,66 \%$ pernah melakukan plagiat isi tulisan secara keseluruhan dengan cara mengganti nama penulis dengan namanya sendiri. Selain pelanggaran tersebut, mahasiswa juga pernah melakukan penulisan artikel dengan tidak mencantumkan kutiban. Hasil data di lapangan ada 36 mahasiswa atau $60 \%$ yang tidak pernah menggunakan kutiban dalam penulisan. Namun dari jumlah $40 \%$ mahasiswa yang menggunakan kutiban, berdasarkan hasil wawancara ternyata mahasiswa juga pernah tidak jujur dalam penulisannya, yang biasanya dilakukan dalam bentuk tidak memberikan kutiban terhadap paragraf tertentu, meskipun tidak dilakukan terhadap keseluruhan isi tulisan.

Berdasarkan hasil wawancara, pelanggaran hak cipta atas karya tulis dalam bentuk plagiasi atau tidak melakukan pencantuman kutiban juga pernah dilakukan oleh mahasiswa yang telah memahami perlindungan hak cipta, hal ini tentunya menjadi sebuah tolak ukur terhadap kemungkinan lebih besar terjadinya pelanggaran oleh mahasiswa yang belum memahami perlindungan hak cipta. Praktek pelanggaran dalam bentuk pembajakan buku sebagaimana tercantum dalam Pasal 72 juga masih dilakukan oleh mahasiswa. Hal ini bisa dilihat dari jumlah mahasiswa yang melakukan fotocopi buku asli yaitu berjumlah $90 \%$.

Tabel 5

Data Alasan Mahasiswa Melakukan Fotocopy Buku

\begin{tabular}{|c|c|c|c|}
\hline No & Alasan & Hasil kues & $n=60$ \\
\hline \multirow{2}{*}{1} & \multirow{2}{*}{ Praktis dan ekonomis } & Jumlah Mahasiswa & Prosentase \\
\hline & & 36 & $60 \%$ \\
\hline 2 & Buku asli sudah tidak terbit lagi & 12 & $20 \%$ \\
\hline 3 & Perintah dosen & 10 & $16,67 \%$ \\
\hline 4 & Abstain & 2 & $3,33 \%$ \\
\hline
\end{tabular}

Beberapa latar belakang atau alasan mahasiswa yang paham hukum masih melakukan pelanggaran sebagaimana tersebut di atas, tentunya bisa menjadi kajian bagaimana fenomena itu bisa terjadi. Latar belakang mahasiswa yang melakukan fotocopi karena alasan pertama yaitu praktis dan ekonomis menunjukkan jumlah terbesar yaitu sebanyak $60 \%$. Alasan kedua 
mahasiswa yang disebabkan buku asli sudah tidak terbit lagi adalah alasan yang masih bisa ditoleransi sepanjang mahasiswa (pemakai) hanya terbatas untuk digunakan sendiri dan tidak bertujuan untuk memperbanyak secara ekonomis. Alasan berikutnya adalah karena perintah dosen. alasan ini terdapat dua kemungkinan yaitu karena ketidaktahuan dosen yang bersangkutan akan perlindungan hak cipta atau karena buku sudah tidak terbit lagi. Jika kemungkinan pertama yang menjadi alasan, maka tentunya hal ini menjadi fenomena yang perlu diperhatikan juga. Kondisi ideal dalam lingkungan akademik tentunya dosen harus mampu menjadi teladan bagi terciptanya system pendidikan yang menunjang sikap ketaatan pada hukum yang berlaku. Berikut ini hasil tabulasi data yang menunjukkan pengaruh pemahaman hukum mahasiswa terhadap perilaku pelanggaran hak cipta.

Tabel 6

Data Mahasiswa yang Mengetahui Hak Cipta dan Melakukan Pelanggaran

\begin{tabular}{llcc}
\hline No & Jenis pelanggaran & \multicolumn{2}{c}{$\begin{array}{c}\text { Jumlah Mahiswa yang Paham Hak } \\
\text { Cipta, } \mathbf{n}=33\end{array}$} \\
\hline \multirow{2}{*}{1} & $\begin{array}{l}\text { Tidak mencantumkan kutiban } \\
\text { dalam penulisan karya tuli }\end{array}$ & Jumlah mahasiswa & prosentase \\
\cline { 3 - 4 } & Melakukan fotocopy buku asli & 33 & $\mathbf{1 0 0 \%}$ \\
\hline 2 & 33 & $\mathbf{1 0 0 \%}$ \\
\hline
\end{tabular}

Berdasarkan hasil tabulasi data di atas menunjukkan bahwa tingkat pemahaman hukum mahasiswa tidak mempengaruhi tingkat jumlah pelanggaran hak cipta. Hasil wawancara yang pernah dilakukan terhadap mahasiswa pasca sarjana menjelaskan bahwa perilaku plagiat yang pernah dilakukan mahasiswa bisa disebabkan karena tugas dosen yang cukup banyak, contohnya adalah seorang dosen yang memberikan tugas mata kuliah dengan membuat 4 makalah dalam 1 semester. Proses belajar yang tidak kondusif seperti ini sangat memberikan peluang bagi mahasiswa untuk melakukan plagiat. Untuk mengurangi pelanggaran karya tulis dalam bentuk plagiasi tentunya harus ada pemahaman yang sama pada semua pelaku akademik, seperti dosen dan mahasiswa untuk menciptakan kondisi belajar yang sehat dengan bebas plagiasi.

Tingkat pemahaman hukum mahasiswa semestinya dapat mempengaruhi berkurangnya jumlah pelanggaran, namun pada kenyataannya di lapangan tidak demikian. Mahasiswa yang mempunyai pemahaman ternyata $100 \%$ masih melakukan pelanggaran hak cipta. Guna menjelaskan fenomena ini, maka berikut ini akan dijelaskan hubungan pemahaman hukum dengan tingkat pelanggaran hak cipta yaitu melalui teori kesadaran hukum Soerjono Soekamto. Menurutnya kesadaran hukum sebuah masyarakat dapat diukur melalui 4 tahap, yaitu: (a) Pengetahuan hukum; (b) Pemahaman hukum; (c) Sikap hukum (Legal Attitude); dan (d) Pola perilaku hukum.

Pengetahuan hukum adalah bekal pertama yang harus dimiliki oleh seorang mahasiswa. Pada tahap kedua yaitu pemahaman hukum. Pada tahap ini mahasiswa sudah mulai mengerti isi dari undang-undang. Pada penelitian ini, pemahaman mahasiswa diukur melalui 4 indikator yaitu selain mengetahui keberadaan undang-undang hak cipta, mahasiswa juga mengetahui perlindungan hak cipta atas karya tulis, hak ekonomi \& hak moral dan mengetahui pasal gugatan ganti rugi dan pidana. Berdasarkan hasil kuesioner di lapangan menunjukkan data bahwa sejumlah 55,83\% mahasiswa sudah mempunyai pemahaman 
yang baik mengenai isi undang-undang.

Tahapan selanjutnya adalah tahapan ketiga yaitu sikap hukum. Pada tahap ini berdasarkan hasil wawancara di lapangan menunjukkan bahwa mahasiswa masih belum mempunyai sikap hukum sesuai dengan yang diharapkan oleh undang-undang. Hal ini bisa dilihat dari banyaknya mahasiswa yang melakukan pelanggaran yaitu $100 \%$ dari jumlah mahasiswa yang mempunyai pemahaman hukum. Sikap hukum mahasiswa belum menunjukkan sikap positif terhadap perlindungan hak cipta atas karya tulis. Meskipun mahasiswa mempunyai kehendak menghargai hasil karya orang lain, namun belum nampak sikap menerima undang-undang dalam perilaku sehari hari. Pemahaman mahasiswa tentang perlindungan hak cipta dan kehendak menghargai hasil karya orang lain dijadikan suatu penerimaan sikap untuk kebutuhan jangka panjang mahasiswa. Mahasiswa berpendapat bahwa perlindungan hak cipta akan memberikan banyak manfaat bagi masyarakat, khususnya bagi pencipta yang telah menghasilkan karya cipta dan banyak berguna bagi masyarakat.

Bagi mahasiswa yang paham hukum namun masih melakukan pelanggaran, menganggap bahwa perlindungan hak cipta tidak banyak memberikan manfaat dan keuntungan ketika dibutuhkan dalam proses pembelajaran suatu mata kuliah. Pada keadaan tersebut, mahasiswa menganggap bahwa pelanggaran dilakukan tanpa ada yang mengetahui dan tidak mendapatkan sangsi. Sikap ini bisa dilihat pada saat mahasiswa melakukan plagiat dalam pembuatan makalah untuk memenuhi tugas dosen. Keadaan ini juga ditambah sikap dosen pengampu mata kuliah yang tidak melakukan peneguran terhadap hasil makalah mahasiswa yang dilakukan dengan cara plagiasi. Sikap hukum inilah yang mengakibatkan mahasiswa masih sering melakukan pelanggaran.

Pemahaman mahasiswa yang masih belum mempunyai sikap positif dan mengganggap bahwa perlindungan hak cipta tidak memberikan keuntungan dan manfaat banyak dalam proses pembelajaran, maka pada tahap berikutnya, tahap keempat, mahasiswa secara tidak langsung juga belum mampu berperilaku hukum yang baik sebagaimana yang diharapkan oleh undang-undang. Peraturan tentang hak cipta belum ada proses internalisasi dalam diri mahasiswa, sehingga peraturan hanya bersifat formal saja. Kondisi ini ditambah dengan latar belakang budaya masyarakat Indonesia yang mempunyai budaya sosial, dimana ilmu adalah sesuatu yang tidak harus dimiliki oleh satu orang saja, tapi juga dibagikan bersama untuk mendapatkan kemanfaatan. Teori ini telah menunjukkan bahwa mahasiswa yang mempunyai pemahaman hukum belum tentu mempunyai kesadaran hukum yang baik pula. Data di lapangan menunjukkan bahwa mahasiswayang mempunyai pemahaman hukum, semuanya pernah melakukan pelanggaran hak cipta (100\%). Hal ini menunjukkan bahwa mahasiswa belum mempunyai kesadaran hukum yang baik akan perlindungan hak cipta atas karya tulis.

Berdasarkan hasil analisis data lapangan di atas, peneliti berpendapat bahwa kewajiban bagi mahasiswa untuk mempunyai kesadaran hukum terhadap perlindungan hak cipta adalah bukan kewajiban semata-mata karena keberadaannya yang diatur melalui undang-undang dan adanya sangsi. Namun yang menjadi lebih penting dalam perlindungan hak cipta atas karya tulis adalah proses pembelajaran untuk berperilaku jujur dan mampu menghargai hasil karya orang lain. Perilaku ini akan mampu menciptakan generasi bangsa yang berkarakter dan berkepribadian sehingga menjadi bangsa yang bermartabat.

\section{Upaya Peningkatan Kesadaran Hukum}

UIN Maulana Malik Ibrahim adalah salah satu Perguruan Tinggi Negeri yang berdasarkan nilai-nilai agama Islam. Guna mewujudkan cita-citanya untuk menjadi perguruan tinggi yang Ulul Albab, maka UIN Maliki Malang mempunyai visi yaitu kedalaman spiritual, keagungan akhlak, keluasan ilmu dan kematangan profesional yang merupakan penerjemahan dari model pengembangan pendidikan Ulul 
Albab. Visi ini tentunya harus dipahami oleh semua pelaku akademis di lingkungan UIN Maliki termasuk mahasiswa.

Sebagaimana pendapat Muhaimin dalam bukunya Pengembangan Pendidikan Ulul Albab yang menyatakan bahwa Ulul Albab adalah orang yang memiliki akal yang murni, yang tidak diselubung oleh kulit, yakni ide yang dapat melahirkan kekacauan dalam berpikir. ${ }^{8}$ Demikian juga yang diharapkan dari mahasiswa yang mendapatkan pendidikan di UIN Maliki Malang, tentunya harus menjadi mahasiswa yang mampu memberikan teladan yang baik dalam membuat hasil karya tulis yang lahir murni dari ide sendiri dan tidak mengambil hasil karya orang lain yang bukan menjadi haknya

Ulul Albab digambarkan sebagai seseorang intelektual yang mempunyai kedalaman spiritual (QS. Al-Baqarah: 197), pengetahuan yang luas (QS. Ali-Imran: 190), dan mempunyai kemauan kuat untuk melakukan perubahan masyarakat ke arah yang lebih baik lewat tindakan maupun keteladanan (QS. Ar-Ra'd: 19-22). Jika proses belajar dilandasi dengan kedalaman spiritual, keagungan akhlak, keluasan ilmu dan kematangan professional, maka tidak akan terjadi pelanggaran atas karya cipta yang dilakukan oleh mahasiswa UIN Maliki Malang.

Penerapan prinsip Ulul Albab dalam proses pembelajaran di kelas menuntut mahasiswa mempunyai kejujuran dalam menulis dan mampu menghargai hasil karya tulis orang lain dan tentunya mampu menjadi teladan bagi mahasiswa di perguruan tinggi yang lain dalam hal akhlak yang dimilikinya. Dengan demikian, mahasiswa UIN akan lebih mudah menjadi mahasiswa yang sadar hukum. Upaya perlindungan atas hak moral pencipta juga telah dilakukan oleh Kementrian Pendidikan Nasional yaitu dalam bentuk diterbitkannya Peraturan Menteri No. 17 Tahun 2010 tentang Pencegahan dan Penanggulangan Plagiat di Perguruan Tinggi. Melalui Permen tersebut pimpinan perguruan tinggi diberikan kewenangan

${ }^{8}$ Jamal Lulail Yunus, Leadership Model, (Malang: UIN Press, 2009), h. 68 malakukan pencegahan plagiat yaitu melalui tindakan preventif. Beberapa tindakan preventif yang disebutkan di dalam peraturan adalah sebagai berikut: (a) Pimpinan perguruan tinggi dapat menetapkan kode etik penulisan dan melakukan pengawasan terhadap penggunaan gaya selingkung penulisan bagi mahasiswa, dosen, tenaga kependidikan dan peneliti; (b) Melampirkan surat pernyataan bebas plagiat pada setiap hasil penelitian dan pembuatan tugas akhir seperti skripsi, tesis dan disertasi; (c) Mewajibkan bagi semua hasil karya tulis mahasiswa, dosen, tenaga kependidikan dan peneliti dipublikasikan melalui media elektronik seperti melalui Portal Garuda.

Beberapa upaya yang dapat dilakukan oleh UIN Maulana Malik Ibrahim adalah sebagai berikut: (a) Sosialisasi undang-undang hak cipta dalam bentuk kuliah umum atau seminar; (b) Penambahan materi tentang plagiat dalam mata kuliah metode penelitian; (c) Evaluasi terhadap penugasan pembuatan makalah oleh dosen; dan (d) Penambahan materi pada buku pedoman penyusunan penelitian (skripsi, tesis dan disertasi) yaitu dengan memasukkan aturan Permendiknas Nonor 17 Tahun 2010.

\section{KESIMPULAN}

Berdasarkan pembahasan penelitian di atas, berikut ini adalah beberapa kesimpulan yang dapat diambil: (1) Berdasarkan hasil kuesioner dan wawancara di lapangan, menunjukkan bahwa mahasiswa UIN Maliki Malang yang paham terhadap perlindungan hukum atas karya cipta masih separo dari jumlah mahasiswa yang ada atau sebanyak $55.83 \%$. Keadaan ini perlu dijadikan perhatian bagi lembaga untuk memberikan pemahaman terhadap sebagian mahasiswa yang masih belum mengerti. Pemahaman hukum mahasiswa atas karya cipta mempunyai dampak terhadap perilaku mahasiswa untuk memegang prinsip kejujuran dalam membuat sebuah karya tulis dan tidak melakukan pelanggaran dalam bentuk plagiasi, seperti membuat artikel (makalah tugas dosen), membuat skripsi dan tesis; (2) Data di lapangan menunjukkan bahwa 
jumlah mahasiswa yang mengetahui hukum pelanggaran hak cipta melalui fatwa MUI hanya berjumlah 17 mahasiswa atau sebanyak $28,33 \%$, sedangkan yang tidak mengetahui jumlahnya lebih besar yaitu $71.67 \%$. Berdasarkan data tersebut, maka mahasiswa dianggap belum memahami perlindungan hak cipta atas karya tulis menurut hukum Islam; (3) Sikap hukum mahasiswa belum menunjukkan sikap positif terhadap perlindungan hak cipta atas karya tulis. Meskipun mahasiswa mempunyai kehendak menghargai hasil karya orang lain, namun belum nampak sikap menerima undang-undang dalam perilaku sehari hari. Berdasarkan hasil wawancara di lapangan menunjukkan bahwa mahasiswa sudah mempunyai pengetahuan hukum dan pemahaman hukum yang baik,

\section{DAFTAR PUSTAKA}

Damian, Eddy, Hukum Hak Cipta, Bandung: Alumni. 2003

Djumhana, M. Djubaedillah. R, Hak Kekayaan Intelektual di Indonesia, Bandung: Citra Aditya Bakti, 1993

Fuady, Munir, Sosiologi Hukum Kontemporer, Bandung: Citra Aditya Bakti. 2007.

Keputusan Fatwa MUI Nomor: 1/MUNAS VII/MUI/5/2005 Tentang Perlindungan Hak Kekayaan Intelektual (HKI) Fatwa MUI. namun masih belum mempunyai sikap hukum sesuai dengan yang diharapkan oleh undang-undang. Hal ini menunjukkan bahwa mahasiswa belum mempunyai kesadaran hukum yang baik akan perlindungan hak cipta atas karya tulis.

Beberapa upaya yang dapat dilakukan oleh UIN Maulana Malik Ibrahim adalah sebagai berikut: (1) Sosialisasi undang-undang hak cipta dalam bentuk kuliah umum atau seminar. (2) Penambahan materi tentang plagiat dalam mata kuliah metode penelitian. (3) Evaluasi terhadap penugasan pembuatan makalah oleh dosen. (4) Penambahan materi pada buku pedoman penyusunan penelitian (skripsi, tesis dan disertasi) yaitu dengan memasukkan aturan Permendiknas Nomor 17 Tahun 2010.

Lindsey, Tim dkk, Hak Kekayaan Intelektual: Suatu Pengantar, Bandung: Alumni, 2006.

Maryadi, Transformasi Budaya, Surakarta: Muhammadiyah University Press. 2000

Saebani, Beni Ahmad, Sosiologi Hukum. Bandung: Pustaka Setia, 2006

Utomo, Tomi Suryo, Hak Kekayaan Intelektual di Era Globalisasi. Yogjakarta: Graha Ilmu. 2009

Yunus, Jamal Lulail. Leadership Model. Malang: UIN Press, 2009 